\title{
PASTURE AGING IN RELATION TO METHOD OF YIELD ESTIMATION
}

\author{
R. S. SCOTт \\ Invermay Agricultural Research Centre, Mosgiel
}

\section{Summary}

A nine-year comparison was made of pasture yields measured by the "mowing and clippings returned" and the "enclosure" techniques of yield estimation. Using the former technique, pasture yields declined at a rate of 270 to $360 \mathrm{~kg} / \mathrm{ha}$ dry matter per annum. Using the "enclosure" technique (which includes the grazing animal) there was no change in pasture production with time.

Both techniques detected significant responses to superphosphate. Results from the "mowing and clippings returned" techniaue approximated absolute pasture production for a period of up to three years. The "enclosure" technique is considered to have provided a reliable. estimate of absolute production over the nineyear period.

\section{INTRODUCTION}

There have been a number of experiments conducted in New Zealand over a 5- to lo-year period in which continuous records of pasture production have been kept. Unfortunately, results have been published as relative yields or authors have not examined their data from the viewpoint of pasture aging — a term used in this paper to indicate a decline in yield as the pasture becomes older.

In a study of the "mowing and clippings returned" and the "enclosure" technique (Lynch, 1947), Elliott and Lynch (1958) published data collected near Hamiton over an eight-year period. Regression analysis of these data by the writer (see Results section) showed a decline in pasture yields under the "mowing and clippings returned" technique as the pasture became older, but no change in pasture production when measured by the "enclosure" technique - i.e., the pasture did not age.

In the southern region of New Zealand, there is a change in farm management towards all-grass farming and it has become a matter of some importance to establish whether the traditional practice.of renewing pastures every 10 years or so is in fact necessary. 
Lynch and Mountier (1954) and Elliott and Lynch (1958) demonstrated that absolute pasture production is dependent upon the method of yield estimation employed. The experiment reported in this paper provides further information on the merits of these two techniques and on pasture aging in a southern enviroament .

\section{EXPERIMENTAL}

Measurements were made within a fertilizer $\mathrm{x}$ rates of stocking experiment reported in part by Scott (1968). The experiment was commenced in 1961 on a nine-year-old sward developed out of browntop and located on rolling hill country. The soil, a hygrous yellow grey-yellow brown earth, was maintained by liming at about $\mathrm{pH} 5.8$. Molybdenum was applied every four years at $140 \mathrm{~g} / \mathrm{ha}$ sodium molybdate and potassium applied at $126 \mathrm{~kg} / \mathrm{ha}$ as potassium chloride from the third experimental year on.

Over the pre-experimental years, superphosphate was applied at an average rate of $282 \mathrm{~kg} / \mathrm{ha}$ supernhosnhate. During the experimental period, two rates of superphosphate application were compared, $126 \mathrm{~kg} / \mathrm{ha}$ and $377 \mathrm{~kg} / \mathrm{ha}$ per annum. In year 13 an application of $1,134 \mathrm{~kg} / \mathrm{ha}$ superphosphate was applied in place of the $377 \mathrm{~kg} / \mathrm{ha}$ dressing.

Stocking rates (described as "low" and "high" in this paper) were increased during the experimental period as follows:

$\begin{array}{lrrrrrrrrr}\text { Experimental year } & 1 & 2 & 3 & 4 & 5 & 6 & 7 & 8 & 9 \\ \begin{array}{l}\text { Pastureage (years) } \\ \text { Low stocking }\end{array} & 9 & 10 & 11 & 12 & 13 & 14 & 15 & 16 & 17 \\ \quad \begin{array}{c}\text { (ewes/ha) } \\ \text { High stocking }\end{array} & 8.6 & 10.4 & 10.4 & 12.1 & 12.4 & 15.8 & 15.8 & 15.8 & 18.8 \\ \quad \text { (ewes/ha) } & 14.8 & 14.6 & 14.8 & 17.5 & 18.3 & 19.8 & 20.3 & 20.3 & 22.2\end{array}$

*Pasture age will be used when referring to years.

Management of the pasture ("enclosure" experiment) was similar to that used in farm practice in the region. It consisted :of set-stccking from lambing until weaning and rotational grazing for the remainder of the year. Stock were maintained on the pasture for all but four to six weeks of the winter when they were on swedes.

Pasture yields were measured on each of the 20 experimental paddocks by the "enclosure" technique, using two pairs of frames per paddock and sampling $1.22 \times 3.32 \mathrm{~m}$ per frame. Under low 
stocking paddocks were 0.575 ha in area and under high stocking 0.336 ha in area.

Within each experimental paddock, an area was fenced from grazing and three plots pegged out for the "mowing and clip pings returned" experiment. These plots plots were treated annually with $126 \mathrm{~kg} / \mathrm{ha}$ and $377 \mathrm{~kg} / \mathrm{ha}$ superphosphate and one plot was kept untopdressed. Samples 1.22 × $6.09 \mathrm{~m}$ were taken from each plot for yield measurement.

The "enclosure" and "mowing and clippings returned" experiments were harvested within a few days of each other, with an average of seven yield cuts being taken each year. These cuts wer taken when pasture reached a height of about- 7 to $10 \mathrm{~cm}$. Occasional hay cuts were taken and in the case of the "mowing and clippings returned" plots, clippings were discarded on these occasions. Yield samples were taken with a reel type mower set to cut at a height of 2.5 to $3.0 \mathrm{~cm}$. Hay cuts were taken with a sickle type mower.

In this paper only results from the "mowing and clipping returned" plots receiving the same superphosphate topdessing as the "enclosure" technique paddock within which they were located will be given. In years 16 and 17 some of the "mowing and clippings returned" plots were closed after it was confirmed that the remainder would provide yields representative of all the plots. Because of the low number of degrees of freedom this provided for an analysis of variance, the data were examined for significance by t-test.

For the purposes of this paper results measured under the "mowings and clippings returned" technique will be described as the "no stock" treatment and results under the "enclosure" technique will be described as the "low" and "high stocking" treatments.

\section{RESULTS}

Yield results are presented in Table 1. They show yields declining in the order of low stocking, high stocking and finally the no stock treatment. This order was recorded under both rates of superphosphate treatments.

Analysis of variance (see Table 1) showed these differences first attained statistical significance in year 11 (the third experimental year). As the variability remained relatively stable throughout the experiment (as shown by the coefficients of variation), it can be concluded that the increasing $F$ values indicate increasing differences between levels of stocking as the pastures become older. 
TABLE 1: PASTURE DRY MATTER YIELDS (kg/ha) (Mean of two superphosphate treatments)

\begin{tabular}{|c|c|c|c|c|c|}
\hline $\begin{array}{c}\text { Pasture Age } \\
\text { (years) }\end{array}$ & No Stock & $\begin{array}{c}\text { Low } \\
\text { Stocking }\end{array}$ & $\begin{array}{c}\text { High } \\
\text { Stocking }\end{array}$ & $F$ Value & $\mathrm{CV} \%$ \\
\hline $11+\dagger$ & $\begin{array}{l}8,030 \text { at } \\
9,200 \mathrm{bA}\end{array}$ & 9,290 a & $\begin{aligned} 8,550 & \text { a } \\
\mathbf{1 1 , 6 5 0} & \text { aA }\end{aligned}$ & $\begin{array}{l}2.84 \\
5.65^{*}\end{array}$ & $\begin{array}{r}13.9 \\
21.4\end{array}$ \\
\hline 12 & $7,940 \mathrm{cB}$ & $10,780 \mathrm{bAB}$ & $11,040 \mathrm{aA}$ & $9.46^{* *}$ & 16.9 \\
\hline 13 & $9,400 \mathrm{c}$ & $11,220 \mathrm{~A}$ & 10,780 В & $8.77^{* * *}$ & 9.6 \\
\hline 14 & $7,800 \mathrm{C}$ & $10,640 \mathrm{~A}$ & $9,630 \mathrm{~B}$ & $11.80^{* *}$ & 14.1 \\
\hline 15 & $7,220 \mathrm{~B}$ & $12,230 \mathrm{~A}$ & $11,600 \mathrm{~A}$ & $33.45 "$, & 14.4 \\
\hline 16 & $6,800 \mathrm{~B}$ & $9,370 \mathrm{~A}$ & $9,030 \mathrm{~A}$ & & \\
\hline 17 & 6,140 B & $11,750 \mathrm{~A}$ & $10,640 \mathrm{~A}$ & & \\
\hline
\end{tabular}

$* P=<0.05, * * P<0.01, * * * P<0.001$

† Duncan's lettering (Duncan, 1955) to bc compared across the table. + Under low stocking, spring and summer production could not be controlled and the severity of defoliation of the pretrimming frames would have resulted in atypical yield estimates.

Results were also analysed by linear regression of yield against pasture age. No change in pasture production with age was recorded under low or high stocking irrespective of superphosphate treatment. Analyses of various treatment combinations also failed to provide any significant linear regressions. No relationship existed between yield and stocking rate. As stocking rate and age both increased together, the data were analysed by partial correlation analysis with stocking rate held constant. This failed to improve the relationship between pasture yield and age.

On the no stock treatment there was a significant linear regression $(\mathrm{P}<0.01)$ in which yields of dry matter declined in the presence of $126 \mathrm{~kg} / \mathrm{ha}$ superphosphate at a rate of $360 \mathrm{~kg}$ / ha/annum. In the presence of $377 \mathrm{~kg} / \mathrm{ha}$ super-phosphate, the regression of no stock against pasture age approached significance $(P<0.05)$. Combined analysis of the no stock treatment in the presence of both superphosphate treatments gave a highly significant regression. Results of these analyses took the form from Elliot and Lynch (1958) :

$$
\begin{aligned}
& \text { ". Treatment Regression equation } r \\
& \text { No stock, } 126 \mathrm{~kg} / \mathrm{ha} \text { superphosphate } \quad \mathrm{Y}=12.30-0.36 x-0.788^{* * *} \\
& \text { No stock, } 126 \mathrm{~kg} / \mathrm{ha} \text { and } 377 \mathrm{~kg} / \mathrm{ha} \\
& \text { superphosphate } \\
& \text { Mowing and clippings returned? } 504 \\
& -\mathrm{kg} / \mathrm{ha} \text { superphosphate }+ \text { lime } \quad \mathrm{Y}=17.53-1.04 x-0.869^{* *}
\end{aligned}
$$

fCalculated by the writer from data presented by Elliott and Lynch (1958)

in Table 2, p. 504. As pasture age was not stated, the first experimental year was treated as pasture age $=1$ year. 
PASTURE AGING AND YIELDESTIMATION

TABLE 2: RELATIVE YIELD RESPONSES TO 377 kg/ha SUPERPHOSPHATE

$(126 \mathrm{~kg} / \mathrm{ha}$ superphosphate $=100)$

\begin{tabular}{lccc}
\hline Year & No Stock & Low Stocking & $\begin{array}{c}- \\
\text { High Stocking }\end{array}$ \\
\hline 10 & 105 & 104 & 112 \\
11 & $106^{* *}$ & & $114^{* *}$ \\
12 & $108^{* * *}$ & $93^{* *}$ & 99 \\
13 & $109^{* * *}$ & $109^{* *}$ & $108^{* *}$ \\
14 & $129^{* *}$ & $134^{\prime} 5$ & $121^{* *}$ \\
15 & $127^{*}$ & $129^{* *}$ & $119^{*}$ \\
16 & $132^{* *}$ & $126^{* *}$ & $113^{*}$ \\
17 & $118^{*}$ & $120^{* *}$ & $112^{*}$ \\
\hline
\end{tabular}

* and * Denotes differences $(\mathrm{P}<0.05$ and $P<0.01$, respectively) between $126 \mathrm{~kg} / \mathrm{ha}$ and $377 \mathrm{~kg} / \mathrm{ha}$ superphosphate treatments.

Relative yield responses to superphosphate as measured by the level of grazing treatments are shown in Table 2. In year 10 (second experimental year) no response to superphosphate was detected by any level of grazing treatment. From year 11 onwards all levels of grazing treatments (with the exception of the high stocking treatment in year 12) detected. responses to high phosphate. Relative yield responses between the no stock and low stock treatments showed a highly significant $(\mathrm{P}<0.01)$ correlation $(r=0.923)$ whereas no stock and high stocked treatments showed no significant relationship $(r=0.701)$.

Species yields varied considerably from year to year and are best illustrated in graphical form. Fig. 1 shows the yields of the dominant species.

The only large difference between treatments was in the yield of ryegrass. As relative responses differed little between years, data were examined by linear regression in which ryegrass yields were compared against pasture age. Results are presented in Table 3.

On the no stock treatment ryegrass yields declined $(P<0.01)$ with age, whereas under stock grazing yields increased with age. No relationship was found between ryegrass yields and stocking rate.

On the no stock treatment receiving $377 \mathrm{~kg} / \mathrm{ha}$ superphosphate there was a significant linear regression $(\mathrm{P}<0.05)$ in which cocksfoot yields increased with pasture age, No other significant regressions of species yield against: age' were obtained.

From data presented in Fig. 1 it is apparent that yields of browntop and white clover differed little according to treatment 
$126 \mathrm{~kg}$ /ha Super $377 \mathrm{~kg}$ /ho Super

- NO STOCK - LOW STOCK - - HIGH STOCK
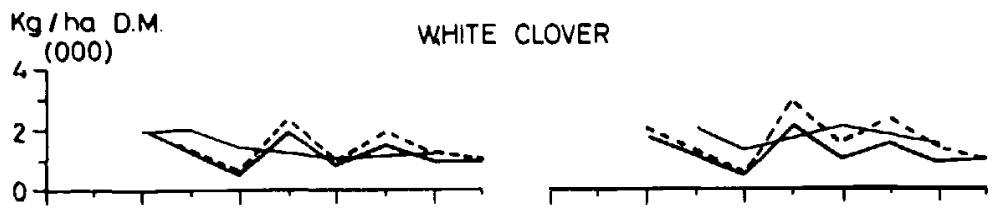

YORKSHIRE FOG
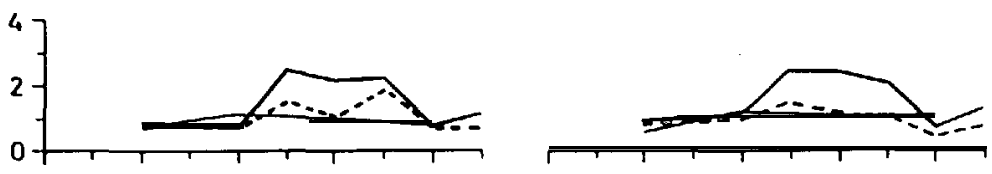

BROWNTOP

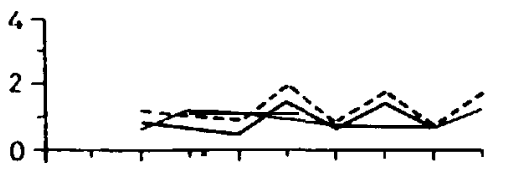

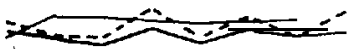

COCKSFOOT
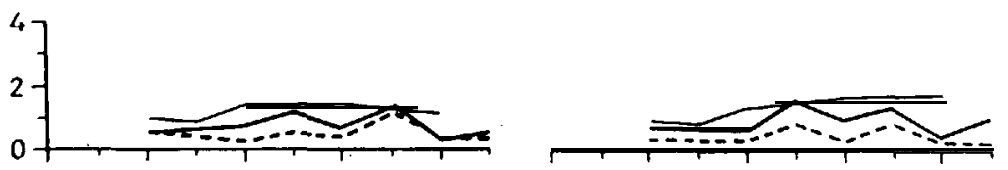

RYEGRASS

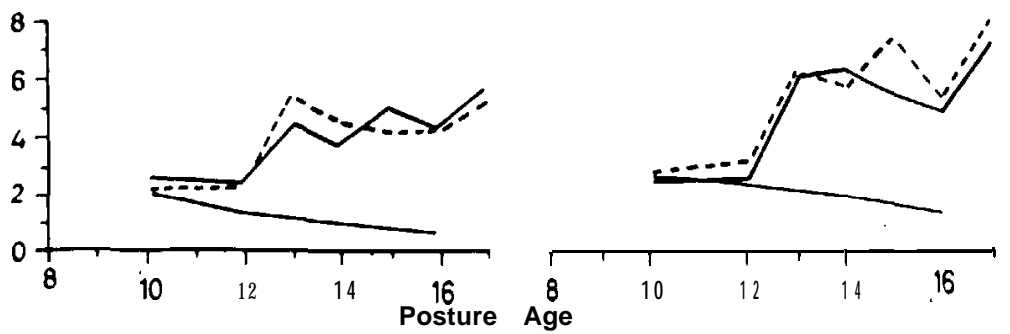

FIG. 1: Yiedd of pasture species in relation to age. 
PASTURE AGING AND YIELD ESTIMATION

TABLE 3: SIGNIFICANCE LINEAR REGRESSIONS OF SPECIES YIELD ON PASTURE AGE

(Thousand $\mathrm{kg} / \mathrm{ha}$ dry matter)

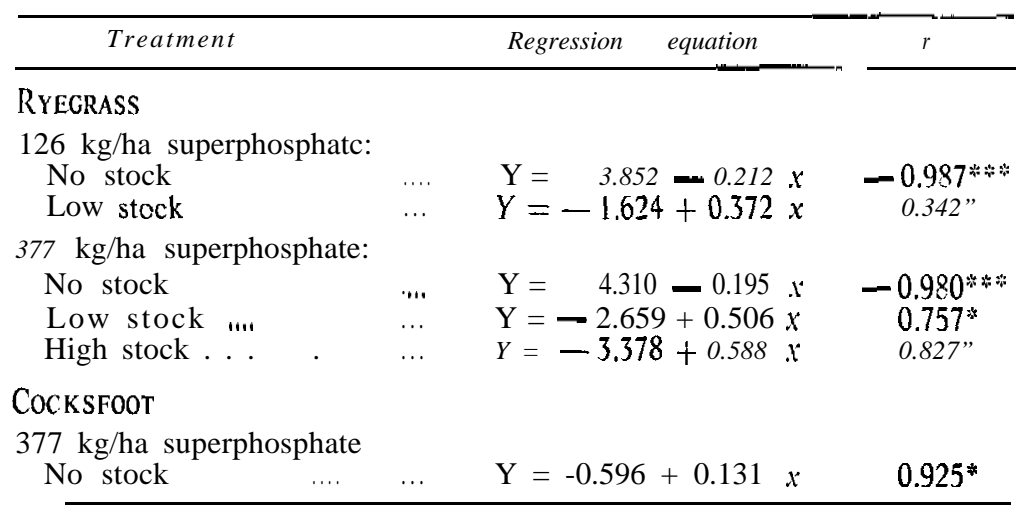

$* P<0.05, \quad * P<0.01, * * * p<0.001$

although their yields were higher under high compared with low stocking. Yields of these species on the no stock treatment did not clearly differ from those under stocking.

Yields of Yorkshire fog were greater on the low stocked treatment than on either the no stock or high stocking treatments.

\section{DISCUSSION}

\section{Technique of Yield Assessment}

Results from this experiment agree well with those extracted from data of Elliott and Lynch (1958), namely, under the "mowing and clippings returned" technique (i.e., the no stock treatment) pasture yields declined with time. The rate of yield decline varied (Table 1) between experiments from $270 \mathrm{~kg} / \mathrm{ha}$ to $1,040 \mathrm{~kg} / \mathrm{ha}$ per annum. Grazed swards, on which yields were measured by the "enclosure" technique, did not decline as the pasture became older. From these findings it can be concluded that the "mowing and clippings returned" technique is unsuited to long-term experiments where a record of absolute pasture yields is required.

Even with the "enclosure" technique, it is difficult to decide whether it is measuring true production. The work of Lynch and Mountier (1954) has shown that, using this one technique, yields differing by $28 \%$ can be obtained when frame areas are 
mown either at weekly or six-weekly intervals. In this regard it would appear that the method adopted in the experiment, of cutting at approximately monthly intervals during the growing season, best simulates rotational grazing and therefore is likely to approximate true production more closely. An exception would be under ultra-high stocking rates where grazing is often below trimming height, or where more intensive rotational grazing is practised.

Differences in pasture yields between the two methods of yield estimation started to develop from the third experimentai years onwards (Table 1). This suggests that the "mowing and clippings returned" technique adequately reflects pasture production under grazing when an area is removed from the influence of the grazing animal for a period of up to two years.

In view of the marked decline in ryegrass yields under "mowing and clippings returned" technique and the relative stability of yields frcm the remaining species, it is likely that this technique will not reflect seasonal patterns of pasture production particularly well. Again, because of this change in species yield, the technique has limitations where information on the uptake of nutrients by pasture is required.

No data were collected which would enable the cause of the difference in yield between the technique to be deter-mind. It would be purely speculative to attempt to draw upon the literature to apportion causes amongst the very large number of factors operating under a non-grazing and a grazing regime.

\section{Suitability of Technigues as Indices of Response to SUPERPHOSPHATE}

Results agree with the findings of Elliott and Lynch (1958) that both techniques measured significant responses to super= phosphate. Without any method of determining true absolute production, it is difficult to determine which method provides the most reliable measure of relative response to superphosphate. One can only rely on the logic that two methods which show a high correlation are more likely to be correct than one that does not correlate with the others. Thus the "mowing and clippings returned" and the "enclosure" technique under low stocking are most likely to provide the best estimate of treatment response.

It must be recognized that in the context of this paper low stocking was in fact higher than average farm levels of stocking. 


\section{PASTURE AGING AND YIELD ESTIMATION}

The fact that the "enclosure" technique under high stocking did not correlate with other techniques is probably due to the variable severity of removal of photosynthetic tissue as a result of seasonal conditions. At times of extreme grazing pressure plants developed a prostrate habit of growth and most of this was removed after the area had been enclosed in a frame prior to the trimming cut.

\section{Pasture Aging}

Results obtained under grazing, using the "enclosure" technique, show that pastures do not age. While there are limitations to the method as an exact measure of pasture yields (as discussed by Lynch and Mountier, 1954), use of the same technique throughout the experimental period will have ensured that the same sources of error were present throughout. For this reason the absence of any pasture aging is considered to be a reliable conclusion.

This finding is of extreme importance in the southern region of New Zealand where the pattern of farm management is changing towards all-grass farming. It means that pasture renewal will only become necessary where deterioration has occurred following poor management, abnormal seasonal climatic conditions, or as a result of depredation by pests and disease.

\section{ACKNOWLEDGEMENTS}

The author wishes to acknowledge the assistance of A. J. Crawford and other staff at Invermay in the field and in the herbage laboratory.

\section{REFERENCES}

Duncan, D. B., 1955: Biometrics, 11: I-42.

Elliott, I. L.; Lynch, P. B., 1958: N.Z. JI ngric. Res., 1: 498-551.

Karlovsky, J., 1962: Trans. joinf Mfg. Comm. IV and V, int. Soc. Soil Sci., New Zealand: 726-30.

Lynch, P. B., 1947: N.Z. Il Sci. Technol., 28A: 385-405.

Lynch, P. B.; Mountier, N. S., 1954: N.Z. JI Sci. Technol., 36A: 375-85. Scott, R. S., 1968: Proc. N.Z. Soc. Anim. Prod., 28: 53-64.

\section{DISCUSSION}

To a question from Smetham (Lincoln College) concerning species yield, particularly legumes, Scott stated that no differences from start to finish had shown in point analysis. During (Ruakura) suggested there 
might be a possible nitrogen deficiency caused by a breakdown of the fertility cycle, such as in the rotting of dead herbage. Scott agreed that this could occur and there had been visual symptoms under the mowing and clipping system, but not under stocking. Roberts (Massey) asked whether, since there were fairly close intervals between mowings, there was a possibility of picking up clippings from a previous mowing. Scott said that dead herbage was separated and usually represented about $2 \%$ of the cut herbage so this would not be a factor. There was no possibility of pest damage being an influence as regular use was made of DDT and, after its prohibition, of organophosphates. O'Connor (Lincoln College) asked if the high stocking method gave a true record of $\mathrm{P}$ response and whether this response was of a different kind under low and high stocking rates, but Scott said no differences were shown in soil tests. White (Lincoln College) asked whether, in view of Miss Radcliffe's paper, the difference technique might have been more appropriate under the low stocking. Scott agreed that that technique would have given better results in high pasture which occurred under very low stocking. Brougham (Palmerston North) inquired which of the techniques used showed how much the animals were eating, which he thought was quite important. Of the two techniques compared in the paper, one was totally unrelated to pasture consumption. Techniques required for a fertilizer experiment were often quite different from those needed in a grazing trial. Scott agreed that it was important to know what animals ate, but this had not been measured here. Judging by the yields measured under the "enclosure" technique they had been consuming round about $1,200 \mathrm{lb}$ DM per ewe. 